\title{
Some Aspects of the Evolution of Inflation-Unemployment Tradeoff
}

\author{
Venelina G. Trifonova
}

\begin{abstract}
The key objective of the paper is to analyze the evolution of the inflation-unemployment tradeoff. Particularly, the study provides an overview of the present empirical evidence of the inflation-unemployment tradeoff and the natural rate of unemployment, mainly in the OECD countries and the Euro area member states.
\end{abstract}

Index Terms-European union, inflation-unemployment relationship, global financial crisis.

\section{INTRODUCTION}

Economic policy debate is often related with the so-called „menu” of possible choices between the rate of inflation and the rate of unemployment. A long tradition suggests that such a tradeoff exists and as its hearth is a statement about the effects of monetary policy. As Ball and Mankiw [1] argue: "According to conventional macroeconomic theory, the inflation-unemployment tradeoff is central to understanding not only the effects of monetary policy but also other policies and events that influence the aggregate demand for goods and services".

The present study aims to make an overview of the present empirical evidence of the inflation-unemployment tradeoff and the natural rate of unemployment, mainly in the OECD countries and the Euro area member states. The natural rate of unemployment or so-called 'non-accelerating-inflation rate of unemployment' (NAIRU) can be viewed as the unemployment rate that the economy reaches in the long period. The natural rate of unemployment could occur with any rate of inflation and would do so as long as the expected rate of inflation is equal to the actual inflation rate.

Large body of empirical work on inflation-unemployment dynamics exists. The classical dichotomy has great attraction as a tenet of long-run macroeconomic theory, but the papers by L. Ball [2], [3] give attention on the rise in European unemployment in the 1980s. Ball [2] shows that countries with largest decreases in inflation and longer disinflationary periods experienced larger increases in their natural rate of unemployment. In his paper in 1999, Ball establishes the link to the monetary policy: countries that failed to pursue expansionary monetary policy in the early 1980s (as measured by changes in interest rates) experienced larger increases in their natural rates than did countries pursuing

Manuscript received March 27, 2013; revised May 29, 2013. This work was supported by the Science Fund of the University of National and World Economy (UNWE), Sofia.

V. G. Trifonova is with the University of National and World Economy (UNWE), Faculty of General Economics, Department of Economics, Sofia, Bulgaria (e-mail: venelina_trifonova@abv.bg). expansionary monetary policy.

\section{EVOLUTION OF INFLATION-UNEMPLOYMENT TRADEOFF}

Nowadays all central banks face the key challenges caused by the inflation-unemployment tradeoff, namely that the price stability can be reached only at the expense of higher unemployment. Besides, the correlation between the cost of inflation and the cost of unemployment usually is a rising function of the degree of non-flexibility of the labour market. The inflation-unemployment relationship suggests that the design of the optimal monetary policy should be balanced amongst the price stability and the fight against the low employment. Nevertheless, a large part of the empirical literature, dedicated to the monetary policy's design, argues that the optimal monetary policy is characterized either with zero inflation or with small deviations from the price stability. Zero inflation is a basic result of the analyses made by many authors [4], etc. A shortcoming of these analyses is the lack of labour market flexibility which is the key ingredient in generating a persistent unemployment as well as strong volatility of unemployment. Attention is also paid to the explanation of some empirical trends as inflation persistency, the late reactions to inflation and unemployment as regard to the monetary shocks and the partial appearance of the disinflation shocks.

The evolution of unemployment in Europe is empirically analyzed by many authors. Thus, O. Blanchard and J. Wolfers [5] consider 15 countries of OECD during the period 1960-1990 and record a growth in the unemployment rate from $1.7 \%$ at the beginning of 1960 s up to $11 \%$ in the middle of 1990s. Behind this trend they notice the following factors: a) negative external shocks leading to a rise in unemployment rate; b) institutions in the labour market and their behavior influencing on the unemployment's origin: some institutions may determine its high rate (known as labour market rigidities); c) interactions between the negative external shocks and the labour market institutions. According another research based on data for NAIRU during the period 1980-1990, the results made demonstrate a rise in NAIRU in almost all countries of OECD. The natural rate of unemployment shifts into the interval from $1.4 \%$ for US and Portugal to $9.3 \%$ for Ireland. The reason for this dynamics is the restrictive monetary policy which aim is to run down the inflation rate. Countries that reduced their inflation rate during this period, however, usually suffered recessions and short-term increasing of unemployment. But the consequences from the disinflation are different for the different countries. For example in some countries the unemployment goes down after several years, while in others 
- NAIRU rises and the unemployment remains high. Some authors [6] explain these differences mainly with the conduct of the monetary policy. Some central banks implement more restrictive monetary policy in order to cut inflation, but when a recession occurs, they change their monetary policy path and implement more expansionary policy. Therefore, the rate of unemployment is reduced. Other central banks undertake and maintain their monetary policy restrictive which determine high persistence of the unemployment. Federal Reserve System is one of the central banks with the strongest reaction during this period by a sharp reduction of the interest rates, despite the lack of a strong decrease in inflation rate. In comparison, many European central banks do not react aggressively to the recession occurred and do not implement weak monetary policy until the inflation process to be completely disregarded. Apart of it an important factor also is the exchange rate which leads to a slower reduction in interest rates by some central banks. On the basis of his measurement of the effects of hysteresis during this period L. Ball established that the scale of these effects is grater when the central banks react very weak to the recessions [6].

In 1994 E. Phelps made estimations of the unemployment rate in 17 members-states of OECD - that is considered as the "first step in testing the changing natural unemployment rate's theory" [7]. Phelps considers that the key determinants of the unemployment are the following: lags in unemployment process; specific variables for certain member states; external variables as the real interest rate and the world oil price. Phelp's analysis discloses that during 1980s oil price is the basic driving force staying behind the unemployment processes, while the direct taxes are important for explaining the differences in the individual countries of OECD. Lately more country specific factors are added, including the asset prices which are thought to be the main determinant of the US unemployment growth. Karanassou, Sala and Snower take out the rate of unemployment from equations for the labor demand and supply [8: p. 11]. Thus, these authors reveal the following factors: money supply growth; price level; real labour productivity; real wage; employment; labour supply; social security installments as a percentage of the GDP; price inflation; indirect taxes as a percentage of the GDP; real oil prices; real import prices (of commodities and services); external demand (export and import as a percentage of the GDP); private consumption as a percentage of the GDP; public expenditures as a percentage of the GDP and others.

In the middle of 1990s, a decrease in the natural unemployment rate was observed in some European countries (UK, Portugal, the Netherlands and Ireland). During the period of 1985-1997, a decline by 2 percentage points was recorded according to the data from OECD. It is thought that a substantial change of NAIRU is more than 3 percentage points. Some of the factors staying behind this downward trend are the labor market's deformations [9] and the implementation of labour market reforms. These factors were followed by a decline in NAIRU.

Lately in the period 2007-2008 also some important changes of NAIRU were observed. Its powerful increase was seen in Germany, while its substantial fall was observed in Finland, Spain, UK, Ireland, Italy, the Netherlands and others. For some of the above-mentioned OECD countries having a decreasing NAIRU it is typical that this relevant decrease in NAIRU was not accompanied neither with inflation growth, nor with disinflation (namely Finland, Italy and Spain). A decrease in NAIRU does not mean undoubtedly that the rate of inflation will have a permanent growth. According to Ball, the effects of hysteresis are long-term, but not permanent. The restrictive monetary policy leads to a rise in inflation which lasts for a long-term period, but eventually the rate of unemployment could begin to decrease even when the inflation rate is stable. There are empirical analyses about the Philips curve separately for the long-term and the short-term unemployment. They indicate that in many countries the long-term unemployment has smaller effects on the inflation rate and this result is more typical for the countries with longer-term unemployment.

The monetary policy of the current Euro area member states was defined as fully exogenous during the last 20 years. Initially it was formulated by the Deutsche Bundesbank by means of a fixed exchange rate. Since the beginning of $1999-$ the monetary policy has been delegated to the European Central Bank (ECB). The mandate of monetary authorities has been focused on the price stability, while the correlation between the GDP's growth among Germany (Euro area) and some other member states (like Spain) has never been high. Moreover, the recession observed during these years, was partially enforced by the negative financial and economic conditions abroad. For example, during the period 2002-2005 the short-term interest rates were low due to the weak economic growth in Germany, France and Italy - the three biggest economies in the Euro area. However, the short-term interest rates were lower in Spain and other member states. There was also an exogenous variation of the interest rate levels. Thus, the present recession in the above-mentioned countries was partially determined by the financial crisis abroad [10].

The situation in the labor market and the implemented institutional reforms in the economy have key importance for the inflation-unemployment tradeoff. The tax reforms, market liberalization and labor market deregulation are considered as the key measures for improving the economic performance - particularly into the European Union (EU). As a result, the structural reforms are treated as the leading policies for the European countries. Arguments supporting the market institutional reforms are given from many academicians and policy-makers in correspondence with the Lisbon strategy. These reforms are largely discussed, but unfortunately there is a view that they are rarely and partially implemented into practice. However, the reforms are quite costly for the economy and the financial system. The major part from the ongoing debate about these reforms is focused on the labour market. This is based on the negative link between the economic performance and wage rigidities in many countries. This link is strongly monitored in the labor and product markets into the EU [11]. A lot of authors like [12], [13] argue that when the economic performance is measured by the rate of economic growth and the rate of employment and the deregulation is measured by the policy of competition and liberalization the reform, therefore, the results from reforms are related with higher production costs, persistent unemployment and slow economic growth without 
a decrease in inflation.

Some authors examine how the inflation-unemployment tradeoff has been influenced by the lack of reforms [14]. They set up a difference between the short-term and long-term consequences from these reforms: a) short-term consequences are related with large costs or loss of unemployment and welfare; b) long-term consequences are almost totally favorable. As a result, it is possible that the policy-makers could not implement structural reforms if are very sensible to the short-term costs on reforms. The basic conclusions of the authors are as follows: a) the fiscal reforms like those of the EU Stability and Growth Pact enhances this effect; b) the choice of an instrument for reform has a crucial importance for example the corporate tax decrease has a strong influence on the social welfare [15] and respectively on the employment; c) the reforms aiming to reduce the unemployment rate are very different from those directed to an increase in the social welfare. In this regard, when the government aims to create employment the market liberalization aiming to encourage competition seems more efficient from the tax reform. Meanwhile, when the purpose of the government is to improve the general social welfare, the tax reforms seem more favorable than the market reforms.

The global financial crisis starting since 2007 is a combination of a huge financial crisis and a sharp decline in prices (of real estates). During the crisis, the biggest rise in the unemployment rate was observed in two countries - Spain and Ireland - of around $7.5 \%$, followed from the US, UK, Finland and Canada - between $2 \%$ and $4 \%$, followed by Denmark, Austria, Greece, Sweden, New Zealand, Portugal, the Netherlands and others. During the period 2007-2009 the unemployment and production developments were strongly different in some individual countries: for example in Ireland and Spain the unemployment rate risen between $7 \%$ and $8 \%$, while in Ireland the production declined by over $8 \%$, but only in half as concern that in Spain [16].

The global financial crisis of 2007-2009 was the most typical example of a sharp and impressive global rise in the rate of unemployment. As the data of the International Labor Organization demonstrate, the financial crisis was followed by a substantial rise in the overall world unemployment with more than 20 million men and women [17]. The number of people living in extreme poverty (with less than a US dollar per day) increased by around 40 million people and those who lived with below of $\$ 2$ per day increased with over 100 million people. The financial crisis hit most severely such economic sectors as construction, tourism, finance, services and real estates.

The huge rise in unemployment rate in the EU and the US during the time of crisis is explained with the consequences from the decline in production, the financial stress and the fall in real estate prices. The countries that were mostly negatively impacted from the fall in unemployment rate were Italy, Germany, Japan and the Netherlands. However, Germany is an exempt - while it was suffered from the production fall of around $7 \%$, its unemployment rate practically did not run down. This fact shows that apart of the production fluctuations, the unemployment dynamics was also determined by the institutions' activities, the policy-making process and the experience shocks. However, the nature of shocks experienced was different in the US and Germany: in the US economy this was a fall in prices combined with a systemic financial crisis; in Germany this was an external demand shock due to the openness of its economy. In addition to the conventional financial and macroeconomic policies, several specific policies were implemented in order to reduce the unemployment rate, to encourage the wage flexibility and to improve the functioning of labor market institutions. For example, the temporary payment of bonuses was a factor which helped to create employment in countries where the labour productivity was high and the macroeconomic uncertainty was also high. The effect from this measure was to encourage the companies to employ new workers, but not only to increase the working hours of the available workers. On the second place, an opportunity was given for a fast moving from the short-term labor programs with a view to facilitate the labour force mobility between the business sectors. The purpose was to prevent the relevant programs from their transformation into permanent bonuses for the loosing industries. In the US economy and Canada an insurance against the loss of job has already been introduced.

The key driving force staying behind the rising unemployment rate was the change in the economic activity. After a period of economic downturn, since the second quarter of 2009, a GDP growth has been observed in France and Germany mainly as a result from the fiscal measures undertaken than from the markets stabilization. The unemployment is considered as long-term and a key macroeconomic problem for the EU member states. Among the EU member states, the lowest unemployment rates were recorded in Austria (4.1\%), the Netherlands (4.9\%) and Luxembourg $(5.2 \%)$, and the highest in Spain $(22.9 \%)$, Greece (19.2\% in October 2011) and Lithuania (15.3\% in the third quarter of 2011). The unemployment rate might continue to grow and the employment could also begin to grow. As concerns the inflation processes during the global financial crisis often is cited the definition 'credit deflation', which occurred during this period. It stems out from the contraction of money supply and credit. Thus, the situation during the current crisis was quite similar with those during the Great Depression. By contrast, the current crisis was different since the substantial rise in prices of many goods and services due to the different business cycles in the US, China and India and the strong inflation in China due to the increasing money supply for buying US dollars.

During the global financial crisis, the most developed countries recorded inflation rates which were much lower than the targeted inflation rates from their central banks. For example, in the US economy, the low consumption and investment activity led to a significant decline in the prices of oil, metals and row materials, also to a substantial and ongoing reduction in the inflation and inflationary expectations. Sustainable reduction was observed in real estate prices and the negative effect on the households' wealth was worsened. These trends were experienced in parallel with the continuous employment contraction and the unemployment growth in the US economy - up to $8.5 \%$ in the first quarter of 2009. This was the highest level of unemployment since the last 25 years in the US.

The deteriorated economic performance in the Euro area, 
the pessimistic views for the consumption and demand, the rising unemployment rate and the contraction of business incomes and profits, were followed by a continuous declining trend in the consumption and investment in the Euro area. Until the 2007 the inflation, measured by the Harmonized Index of Consumer Prices (HICP) in the Euro area was lower than the ECB target rate of $2 \%$. The reasons for this trend were associated with the fall in energy prices, the abolished increases in wages, the contracted consumption demand and the high level of finished production inventories. Owing to the strong rises in commodity prices, inflation rose significantly in the Euro area in the first half of 2008 and upside risks to price stability mounted over the year 2008. The highest inflation rate in the most advanced economies was recorded in August 2008 - the 12-month inflation rate was over 4\%, while in less developed countries it was 2 times higher - over $8 \%$ for the same month of the year [18]. Less developed economies were characterized by economic overheating followed by an inflation pressure. Another important factor for the rising inflation was the financial package of measures undertaken for providing an unprecedented money and fiscal expansion in the developed countries.

Signals for getting out of the crisis were firstly observed at the end of 2009. In 2010 the Euro area economy was characterized by an economic recovery following the recovery in the world economy. Domestic developments were also contributing to the prevailing positive momentum in 2010 in the Euro area. The outlook for inflation remained moderate, with neither deflationary, nor inflationary pressures over the ECB's monetary policy medium-term horizon.

Nevertheless, tensions in financial markets in the Euro area were still persistent and even renewed in the course of 2010. The main reasons for this trend were the growing market concerns about the sustainability of public finances, especially in Greece, with clear signs of contagion affecting other Euro area government bond markets. This severe stress in some Euro area bond markets has been observed since May 2010. The yield on Greek government bonds reached very high levels compared with the German benchmark bond, but yields on the bonds of some other governments were also affected. Unfortunately, this current sovereign debt crisis has particular negative impact on the macroeconomic development of the Euro area and the future trends for adoption of the euro from the EU member states outside the Euro area. The crisis reveals the strong need for financial support for ailing banking systems, but to some extent also points to uncertainty about various aspects of European sovereign crisis prevention and resolution mechanisms. The high unemployment will be combined with a considerable lack of investments, particularly in production and infrastructure.

\section{CONCLUSION}

The study of the empirical evidence of the inflation-unemployment tradeoff demonstrates large contrasts in the European countries over the last decades. Large disparities are observed in the OECD member states. The global financial crisis starting in 2007 hit hardest such economic sectors as construction, automotive, tourism, finance, services and real estate. This crisis was accompanied by the highest rise in the unemployment rate - the increase of unemployment was estimated of 20 million people. The highest growth in the rate of unemployment was observed in Spain, Ireland, Greece, Portugal and other countries. This trend was driven by the negative effects from the substantial fall in production, the financial turmoil and the fall in real estate prices. The global financial crisis revealed the need of economic rescue plans for working force and the real economy, with rules and policies that lead to a higher employment and a better link between the labour productivity and the wages. The ECB, the IMF and the Federal Reserve implemented a number of measures in order to strengthen the world financial system and the global economy. These measures included restoring credit flows, maintaining and enhancing social protection, such as pensions, unemployment benefits, child support and health care schemes, ensuring enterprise access to credit to avoid layoffs, wage cuts and bankruptcy.

\section{ACKNOWLEDGMENT}

The author thanks to Prof. D.Sc. Statty Stattev, Rector of the University of National and World Economy (UNWE), Sofia, Bulgaria, and member of the Governing Council of the Bulgarian National Bank (BNB).

\section{REFERENCES}

[1] L. Ball and G. N. Mankiw, "The NAIRU in theory and practice," in NBER Working Paper Series, no. 8940, National Bureau of Economic Research, May 2002

[2] L. Ball, "Disinflation and the NAIRU," in Reducing Inflation: Motivation and Strategy, Eds. C. D. Romer and D. H. Romer, Chicago: Chicago University Press, 1997, pp. 167-194

[3] L. Ball, "Aggregate demand and long-run unemployment," Brookings Papers on Economic Activity, vol. 2, 1999, pp. 189-251.

[4] R. Clarida, J. Gali, and M. Gertler, "Monetary policy rules and macroeconomic stability: Evidence and some theory," in Quarterly Journal of Economics, vol. 115, no. 1, 2000, pp. 147-180.

[5] O. Blanchard and J. Wolfers, "The Role of shocks and institutions in the rise of European unemployment: the aggregate evidence," in Economic Journal, vol. 110, 2000.

[6] L. Ball, "Hysteresis in unemployment: old and new evidence," in NBER Working Paper Series, no. 14818, March 2009.

[7] E. S. Phelps, Structural Booms: The Modern Equilibrium Theory of Unemployment, Interest and Assets, Cambridge (MA): Harvard University Press, 1994

[8] M. Karanassou, H. Sala, and D. J. Snower, "The evolution of inflation and unemployment: Explaining the roaring nineties," in Australian Economic Papers, vol. 47, no. 4, 2008, pp. 279-300.

[9] H. Siebert, "Labor market rigidities: At the root of unemployment in Europe," in The Journal of Economic Perspective, vol. 11, no. 3 Summer, 1997, pp. 37-54

[10] G. Jimenez, S. Ongena, and J. L. Peydro, "Credit availability: Identifying balance-sheet channels with loan applications," International Proceedings of The Phillips Curve and the Natural Rate of Unemployment Symposium, Kiel Institute for the World Economy, June 2007.

[11] K. Koedijk and J. Kremers, "Market opening, regulation and growth in Europe," Economic Policy, vol. 23, 1996, pp. 445-467.

[12] Eurostat, "December 2011 Euro area unemployment rate at $10.4 \%$ EU27 at 9.9\%," News Release Euro Indicators, 31 January 2012.

[13] S. Nickell, I. Nunziata, and W. Ochel, "Unemployment in the OECD since 1960s, what do we know?" Economic Journal, vol. 115, 2005.

[14] N. Bokan and H. A. Hallet, "The Impact of tax, product and labor market distortions on the Phillips curve and the natural rate of unemployment," April 2007. 
[15] E. Prescott, "Why Do Americans Work So Much More than Europeans?" Federal Reserve Bank of Minneapolis Quarterly Review, vol. 28, 2004, pp. 2-13

[16] IMF, World Economic Outlook: Rebalancing Growth, Ch. 3, Washington, D.C.: International Monetary Fund, April 2010.

[17] ILO, "ILO says global, financial crisis to increase unemployment by 20 million," Press Release, ILO/08/45, International Labour Organization, October 2008

[18] ECB, "Frankfurt am Main: European Central Bank," Annual Report 2010, April 2011.

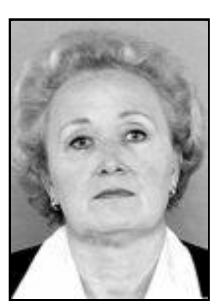

V. T. Trifonova was born in Rousse, Bulgaria on 23 January 1949. She is a Bulgarian economist, working in the fields of monetary economics, international macroeconomics and finance. She graduated from the Higher Institute of Economics "Karl Marx," (currently University of National and World Economy, UNWE), Department of Economics, Sofia.

She works as an associate professor in Economics in Department of Economics, Faculty of General Economics at the UNWE, Sofia. She is affiliated with the international academic and teaching community since 1991 . Over the years she has held a number of visiting positions at several institutions including: University of Warsaw (1992), Ecole Polytechnique (1997), University of Athens (1998),

Kiel Institute for the World Economy (2006), Zhytomyr State Technological University (2009), etc. Her major publications include: "Empirical Evidence of the Monetary Policy Transmission Mechanism in the Euro area," Globa Business \& Economics Anthology, Vol. II, Issue 1, B\&ESI, December 2010; "Endogenous Money and Central Bank's Control on Short-term Interest Rates," Conference Proceedings, IEDRC Thailand Conference ICIF, Bangkok 2012; "Endogeneity of Money in the Light of Financial Registration Equality," Global Business \& Economics Anthology, Vol. II, Selected Papers, B\&ESI, 2012. Her current and previous research interests include monetary theory and policy, endogenous money theory, financial markets, financial crises, European integration process, globalization.

Assoc. Prof. V. Trifonova is a member of Bulgarian Macroeconomic Association and Bulgarian Association of University Women. She is a leader and member of many international and national research projects regarding financial crises, macroeconomic policies, central banking, financial markets, European integration process, etc. 